\title{
Surface Treatment of Dental Materials
}

\section{Key Words : Dental Material}

蒾科分野での代表的な菌冠萻復物を 2 つ挙げ, 金属と セラミックスあるいは金属とプラスチックスを結合させ るための金属表面処理方法と, 桔合のためのメカニズム を解説した。

\section{1.緒言}

歯科材料としての要件は耐久性, 耐食性に優れ, しか あ天然菊の色調に類似した自然感を有することである。 そのため，外観から見えない部分には耐久性に優れた金 属を，外観から見える部分にはプラスチックス，セラミッ クスなどを使用し, 両者を何らかの方法で強固に結合さ せており，結合のためには金属表面を種々の方法で処理 している。今回はこうした歯科における金属の表面処理 について紹介したい。

\section{2. セラミックスと金属との結合における}

\section{表面処理}

\section{1 金属焼付ポーセレンの構造}

金属焼付ポーセレンは歯冠修復物であり，耐久性，耐 食性, 自然感に最す優れたすのとして約 30 年の歴史を誇っ ている。その構造を図 1 に示すが, $0.2 \mathrm{~mm} \sim 0.5 \mathrm{~mm}$ の 厚みの金属の上に $0.7 \mathrm{~mm} \sim 1.2 \mathrm{~mm}$ の厚みのセラミック スを焼付けたものである。使用するセラミックスは単色 ではなく,メタル表面には不透明色セラミックス，その 表首には半透明色, さらに表首には透明色と表層になる に従って透明度を増した層状構造となっており,これら は金属の上に一体として焼付けられる。層状構造にする 理由は, 天然歯は中央に歯䯣があり，その周りには象牙 質, 表首にはエナメル質があり，これらが一体となった 微妙な色調を, 術者らはわずか0.7〜 1.2mm之制限され た厚みの中で再現しなければならないからである。焼付 用ポーセレンとしては100色ほどの色調が揃っており， 患者一人一人の特有の色調を再現する努力が歯科医師と

\footnotetext{
*(㑣)カスプデンタルサプライ（テ480-11 愛知県愛知郡長久手町 大字長汧字下鴨田44-1)

Cusp Dental Supply Co., Ltd. (44-1, Ooaza-Nagakute AzaShimokamoda, Nagakute-cho, Aichi-gun, Aichi 480-11)
}

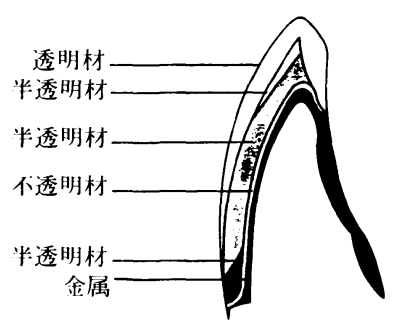

図 1 金属焼付ポーセレンの構造 金属焼付ポーセレンはメタルキャップの上にポーセレ ン（セラミックス）を層状に重ねて焼成する。

歯科技工士相互の協力によって行われている。

\section{2 焼付用合金}

金属焼付用ポーセレンに使用される合金には表 1 に示 すあのがある。歯科用合金として最も重要なことは耐食 性に優れていることであり，その他の必要条件としては， 機械的性質に優れていること，歯型はロストワックス法 で製作されるので鋳造性が良いことも重要である。そし て，焼付用合金の場合にはこれらの要件の他に，セラミッ クスとの熱膨張係数が類似していること，セラミックス 焼成時に合金表面に生成する酸化物の成長が少ない組成 であること，酸化物の色調がセラミックスの色調を阻害 しないあのであること, 加熱処理によって変形が極力少 ないこと，セラミックスの焼成温度より少なくとも 100 ${ }^{\circ} \mathrm{C} \sim 150^{\circ} \mathrm{C}$ は高い固相点であること, セラミックスの色 調を変色させない組成であることなどが挙げられる。現 在, $\mathrm{Au}-\mathrm{Pt}-\mathrm{Pd}$ 系のプレシャス系合金, $\mathrm{Au}-\mathrm{Pd}$ 系や $\mathrm{Au}-\mathrm{Pd}-\mathrm{Ag}$ 系, $\mathrm{Pd}-\mathrm{Cu}$ 系, $\mathrm{Pd}-\mathrm{Ag}$ 系のセミプレシャス 系合金, Ni-Cr-Mo系のノンプレシャス系合金があり， これらの熱膨張係数は $12.7 \sim 14.5 \times 10^{-6} /{ }^{\circ} \mathrm{C}$ に設定され ており，機械的性質については，口空内で咬合力に耐え られる硬さ（Hv）は160 400, 引張り強さ $\left(\mathrm{kg} / \mathrm{mm}^{2}\right)$ は50〜120ほどである（表 2)。またセラミックスの焼成 温度は $900 \sim 980^{\circ} \mathrm{C}$ であることから焼付用合金の融点は $1050 \sim 1350^{\circ} \mathrm{C}$ 位である。 
表 1 歯科用焼付用合金

\begin{tabular}{|c|c|c|c|c|c|c|c|c|c|c|}
\hline \multirow{2}{*}{ 分類 } & \multirow{2}{*}{ 種類 } & \multicolumn{8}{|c|}{ 組成（wt. \%) } & \multirow{2}{*}{$\begin{array}{l}\text { 融点 } \\
\left({ }^{\circ} \mathrm{C}\right)\end{array}$} \\
\hline & & $\mathrm{Au}$ & Pt & $\mathrm{Pd}$ & $\mathrm{Ag}$ & $\mathrm{Cu}$ & $\mathrm{Sn}$ & In & $\mathrm{Ga}$ & \\
\hline プレシャス系 & $\mathrm{Au}-\mathrm{Pt}-\mathrm{Pd}$ & $70 \sim 88$ & $3 \sim 13$ & $1 \sim 10$ & $0.6 \sim 3$ & - & $0.4 \sim 5$ & - & - & $1050 \sim 1300$ \\
\hline \multirow{4}{*}{ セミプレシャス系 } & $\mathrm{Au}-\mathrm{Pd}$ & $10 \sim 52$ & $0 \sim 10$ & $38 \sim 50$ & $0 \sim 1$ & $0 \sim 4$ & $0 \sim 9$ & $0 \sim 9$ & - & $1140 \sim 1310$ \\
\hline & $\mathrm{Au}-\mathrm{Pd}-\mathrm{Ag}$ & $37 \sim 53$ & $1 \sim 3$ & $25 \sim 39$ & $12 \sim 20$ & - & - & $2 \sim 4$ & $0 \sim 5$ & $1150 \sim 1260$ \\
\hline & $\mathrm{Pd}-\mathrm{Cu}$ & $0 \sim 2$ & $0 \sim 1$ & $68 \sim 82$ & $0 \sim 0.5$ & $5 \sim 20$ & - & $0 \sim 10$ & $0 \sim 10$ & $1100 \sim 1290$ \\
\hline & $\mathrm{Pd}-\mathrm{Ag}$ & - & $0 \sim 1$ & $55 \sim 60$ & $28 \sim 33$ & - & $0 \sim 12$ & $0 \sim 7$ & - & $1190 \sim 1320$ \\
\hline \multirow{2}{*}{ 分類 } & \multirow{2}{*}{ 種類 } & \multicolumn{8}{|c|}{ 組成（wt. \%) } & 融点 \\
\hline & & $\mathrm{Ni}$ & $\mathrm{Cr}$ & Mo & $\mathrm{Fe}$ & $\mathrm{Al}$ & $\mathrm{Si}$ & $\mathrm{Be}$ & Co & $\left({ }^{\circ} \mathrm{C}\right)$ \\
\hline \multirow[t]{2}{*}{ ノンプレシャス系 } & $\mathrm{Ni}-\mathrm{Cr}-\mathrm{Mo}$ & $74 \sim 83$ & $8 \sim 22$ & $2 \sim 15$ & $0 \sim 20$ & $0 \sim 2$ & $0 \sim 3$ & $0 \sim 2$ & & $1200 \sim 1350$ \\
\hline & $\mathrm{Co}-\mathrm{Cr}$ & & $22 \sim 32$ & $0 \sim 3.5$ & & & & & 75 & $1290 \sim 1350$ \\
\hline
\end{tabular}

表 2 焼付用合金の機械的性質

\begin{tabular}{|c|c|c|c|c|}
\hline & & 硬さ (Hv) & 引張り強さ $\left(\mathrm{Kg} / \mathrm{mm}^{2}\right)$ & 伸び (\%) \\
\hline プレシャ & メタル & 168 & 58.9 & 3.8 \\
\hline セミプレシャス & $\mathrm{Au}-\mathrm{Pd}$ 系 & 241 & 71.5 & 13.4 \\
\hline メタル & $\mathrm{Au}-\mathrm{Pd}-\mathrm{Ag}$ 系 & 210 & 58.9 & 5.5 \\
\hline & Pd-Cu系 & 294 & 95.7 & 2.7 \\
\hline & $\mathrm{Pd}-\mathrm{Ag}$ 系 & 200 & 67.9 & 8.9 \\
\hline ハンプレシャスメ & ル Ni-Cr-Mo系 & 365 & 114.7 & 3.6 \\
\hline
\end{tabular}

表 3 焼付用ポーセレンの組成（wt.\%）

\begin{tabular}{l|r|l|l}
\hline $\mathrm{SiO}_{2}$ & 60.26 & $\mathrm{SnO}_{2}$ & 0.02 \\
$\mathrm{Al}_{2} \mathrm{O}_{3}$ & 15.28 & $\mathrm{In}_{2} \mathrm{O}_{3}$ & 1.10 \\
$\mathrm{~K}_{2} \mathrm{O}$ & 9.47 & $\mathrm{ZrO}_{2}$ & 0.35 \\
$\mathrm{Na}{ }_{2} \mathrm{O}$ & 5.87 & $\mathrm{Fe}_{2} \mathrm{O}_{3}$ & 0.028 \\
$\mathrm{BaO}$ & 3.33 & $\mathrm{TiO}_{2}$ & 0.45 \\
$\mathrm{CaO}$ & 1.47 & $\mathrm{~V}_{2} \mathrm{O}_{5}$ & 0.03 \\
$\mathrm{MgO}$ & 0.47 & & \\
\hline
\end{tabular}

\section{3 焼付用ポーセレン（セラミックス）}

焼付用ポーセレンの組成を表 3 に示すが長石 $\left(\mathrm{K}_{2} \mathrm{O}\right.$ ・ $\mathrm{Al}_{2} \mathrm{O}_{3} \cdot 6 \mathrm{SiO}_{2}$ ) が80 95\%であり，ほとんど長石ガ ラスと呼んだ方がふさわしい位である。そして，その他 に融点を下げるために $\mathrm{CaO}, \mathrm{MgO}, \mathrm{B}_{2} \mathrm{O}_{3}$ などのフラッ

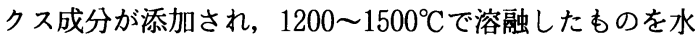
中急冷しフリットとする。フリットは更に粉研し，その 後, 一塊に固めて $700 \sim 1100^{\circ} \mathrm{C} て ゙ 一$ 定時間保持して熱処 理を行う ${ }^{1)}$ 。熱処理後は紛砕し, $2 \sim 90 \mu \mathrm{m}$ の範囲内で 粒度分布を定めて仕上げる。焼付用ポーセレンの製造工 程で熱処理を行う理由は, 原材料のガラスは $7 \sim 8 \times$ $10^{-6} /{ }^{\circ} \mathrm{C}$ 熱膨張係数であり，このままでは合金に焼付 かないので焼付用ポーセレンの熱膨張係数を合金に近似 させるためである。この熱処理によってガラス中にはリュ 一サイト結晶 $\left(\mathrm{K}_{2} \mathrm{O} \cdot \mathrm{Al}_{2} \mathrm{O}_{3} \cdot 4 \mathrm{SiO}_{2}\right)$ が析出し, リュ 一サイト結晶自身は $20 \times 10^{-6} /{ }^{\circ} \mathrm{C}$ とうう高膨張の結晶で あり，マトリックスガラスとの相互関係で合金の熱膨張 係数に近似した $12.0 \sim 13.5 \times 10^{-6} /{ }^{\circ} \mathrm{C}$ の熱膨張係数とな る。しかし，熱処理温度と焼付用ポーセレンの焼成温度
が類似しているため，熱処理が確実にされていないと焼 付用ポーセレンの焼成過程でリューサイト結晶が成長し たり，新たに析出したり，逆に減少したりするため焼付 用ポーセレンの熱膨張が変動する。そして合金との熱膨 張が不適合となり，ポーセレン中にクラックが発生する ことが問題となっていた（図 2)。しかし，近年熱膨張 の変動のない焼付用ポーセレンが開発され，この問題は 解決された ${ }^{2), 3)}$

\section{4 金属焼付ポーセレンの製作工程}

金属焼付ポーセレン製作する前にはシェイドテーキン グといって, 色見本を使用して患者の歯が色見本の何番 にあたるか，また部分的に着色していればそれらをメモ に記しておく。そして，虫歯になった部分を削り取り， 患者の口の中をシリコーン系印象材などで印象する。こ の印象材中に超硬質石膏を注入して硬化させると, 患者 の歯型模型ができる。その後, 歯科技工士に模型が手渡 され，削除部分の歯冠をワックスで回復した上で，ポー セレン焼成部分にあたる所のワックスを除去すると，ワッ クスキャップができ上がる。それに湯道を付着し，リン 酸塩系鋳型材で埋没する。約 1 時間後に加熱炉に入れ $800^{\circ} \mathrm{C}$ まで昇温したものを取り出し，鋳造機内に設置し， 同時に焼付用合金を溶融して鋳造しメタルキャップとな る。鋳型から掘り出したメタルキャップは湯道を切断し, 歯科用研削材で表面を滑らかに整え，アセトンなどの溶 液中で超音波洗浄を行う。洗浄したメタルキャップは, 污物の焼却, 酸化膜の生成を目的として歯科用加熱炉で 700 $980^{\circ} \mathrm{C}$ まで加熱する。焼付用ポーセレンは粉末状と なっており，これを蒸留水で練和し，筆ですくい上げて， メタルキャップの上に盛り上げ, 震動を与えて余剩水を ティッシュペーパーで吸水し, 密度を高めていく。同様 にして何色もの色調を層状に盛り上げ，吸水を絽り返し， 歯冠形態より約 $12 \%$ 大きくして $700 \sim 960^{\circ} \mathrm{C}$ 前後で焼成後, ポーセレン表面を歯科用研削材で微細な表面性状を付与 した後, 再び超音波洗浄し, グレーズ焼成をして完成す る。 


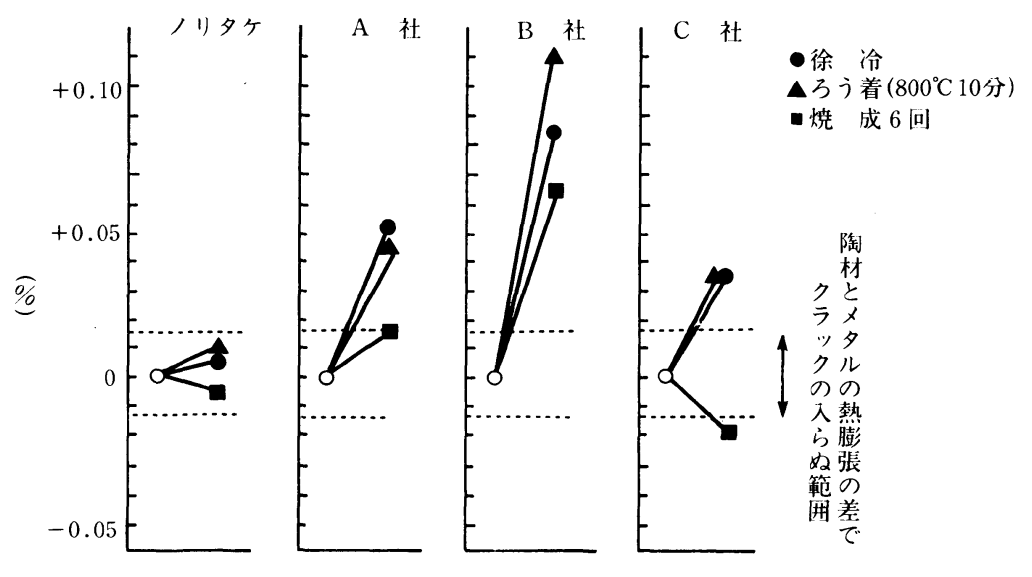

図 2 焼付用ポーセレンの熱膨張の変動 焼付用ポーセレンは焼付後の冷却速度, ろう着時, 焼成の絽り返しによって変動する。 図は 1 回焼成，急冷を基準とした場合の変動。

\section{5 合金とポーセレン（セラミックス）の結合機構}

合金とポーセレンを焼付けるためには両者の熱膨張係 数が近似していること，合金表面が清浄でポーセレンと よくぬれることが前提条件である ${ }^{4)}$ 。結合機構の理論と しては

(1)化学的結合

(2)機械的結合

(3)ファンデルワールスカによる結合

の 3 つがあるが5)，これらは単独で働くのではなく，3 つが相互に㗢くが，これらの中でも最も大きく寄与する のが(1)の化学的結合であり, 次いで(2)の機械的結合, (3) のファンデルワールスカによる結合であり, ファンデル ワールスカによる結合はわずかであると言われている。 そして(1), (2)は表面処理と大きくかかわっているので次 に詳細に述べる。

\section{5. 1 化学的結合}

化学的結合とは合金を $700 \sim 980^{\circ} \mathrm{C}$ 加熱処理し，合金 表面に生成した酸化物とポーセレン中の酸化物が化学的 に結合するという理論である。例えば焼付用合金として $\mathrm{Au}-\mathrm{Pt}$-Pdのみ使用した場合, ポーセレンとはほとんど 焼付かないが，この合金の中にSn，Inなどを0.3〜 $5 \%$ 添加すると強固に焼付く。そしてSn, Inなどの添加は 合金の硬さ, 引張り強さなどを向上させるので好都合で ある。Au-Pt-Pd合金にSn，Inを添加すると加熱処理に よって合金表面には $\mathrm{SnO}_{2}$ および $\mathrm{In}_{2} \mathrm{O}_{3}$ の酸化膜が生成 され，この酸化膜とポーセレン中の $\mathrm{SnO}_{2}, \mathrm{In}_{2} \mathrm{O}_{3}$ とが 結合すると言われている ${ }^{6)}{ }^{71}$ 。ポーセレンにおいてあ, メタルキャップ表面に焼成するポーセレンは不透明でメ タル色を隠す必要があり，この部分に使用するポーセレ ンに $\mathrm{SnO}_{2}, \quad \mathrm{In}_{2} \mathrm{O}_{3} を 5 〜 20 \%$ 添加することは ${ }^{8)}$ メタル色 を遮へいし，合金との結合にあ関与するので好都合であ
る。以上のようにプレシャス系合金やセミプレシャス系 合金はAu-Pt-Pdが主体であることから $\mathrm{SnO}_{2}, \mathrm{In}_{2} \mathrm{O}_{3}$ の 酸化膜を利用することが多いが，セミプレシャス系合金 の中でPd-Cu-Ga系合金の場合は $\mathrm{Ga}_{2} \mathrm{O}_{3}, \mathrm{SnO}_{2}, \mathrm{CuO}$ の複合酸化膜が生成され ${ }^{9)}$ ，ポーセレンとの結合に関与 している。しかし，この酸化膜は焼成回数を增すと合金 表面よりはく離しやすく，結合強度としては充分ではな い。一方，Ni-Cr-Mo系のノンプレシャス系合金の場合 には微量添加元素としてBeが添加されているか，いな いかで異なり，Beが1.5〜2.0\%添加されている場合には $\mathrm{BeO}$ の単層の酸化膜となり, 添加されていない場合には $\mathrm{Cr}_{2} \mathrm{O}_{3}$ と $\mathrm{NiCr}_{2} \mathrm{O}_{4}$ の酸化膜となる ${ }^{10)}$ 。 $\mathrm{BeO}$ の酸化膜はち 密で焼成回数の繰り返しによっても成長が少ないので, ポーセレンとの結合は強固で口腔内装着後のはく離のト ラブルはほとんどない。一方, $\mathrm{Cr}_{2} \mathrm{O}_{3}$ と $\mathrm{NiCr}_{2} \mathrm{O}_{4}$ の酸 化膜の場合には焼成回数を繰り返すと酸化膜が成長して 厚くなり，口腔内に金属焼付ポーセレンを装着後，酸化 膜がポーセレンに付着した状態ではく離することがしば しばある（図3，4）。従って現状においてはNi-CrMo系合金を使用する場合にはBeを $2 \%$ ぼ添加した合 金を使用することが多い。 $\mathrm{Be}$ の人体に対する有毒性を 心配することからBeにかわる元素をメ一カ一側がこぞっ て探している。

\section{5. 2 機械的結合}

機械的結合とはメタルキャップの鋳造後にメタルキャッ プ表面を歯科用研削材で滑らかに仕上げるが，その時形 成された微細な凹凸にポーセレンが入り込みインターロッ キング効果で結合するという理論である。歯科用研削材 としては $\mathrm{SiC}$ 砥粒および $\mathrm{Al}_{2} \mathrm{O}_{3}$ 砥粒をビトリファイドボ ンドを結合材として焼き固めたものや，カーバイドバー が使用され，プレシャス系合金の場合には $\mathrm{Al}_{2} \mathrm{O}_{3}$ の研削 


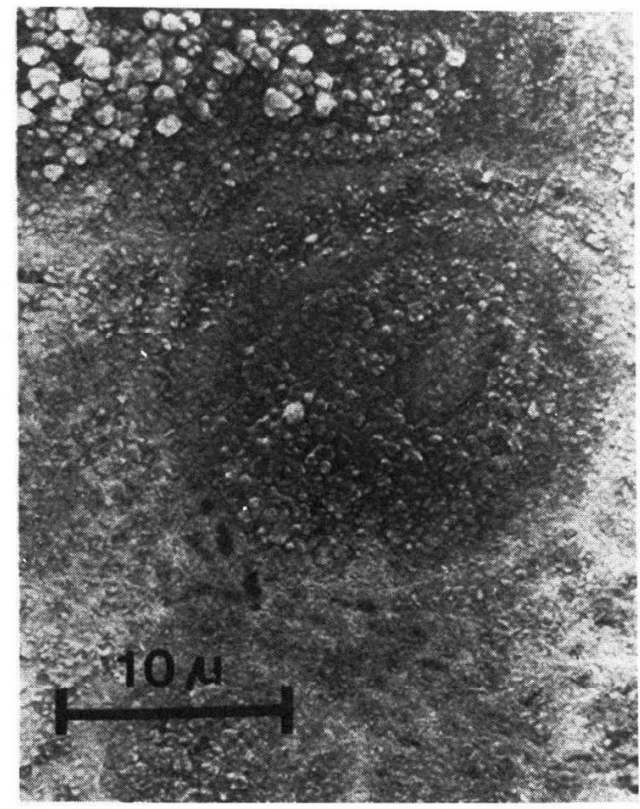

図 3 Beを $2 \%$ 含有したNi-Cr-Mo系焼付用合金の酸化膜 $\mathrm{BeO}$ 酸化膜はち密で加熱の絽り返しによっても成長 が少ない。 $960^{\circ} \mathrm{C}$ で10分加熱後の写真（3000倍）

材かカーバイドバー，セミプレシャス系合金でも合金が 軟かい場合にはプレシャス系と同様の研削材，硬いもの では $\mathrm{SiC}$ 研削材と $\mathrm{Al}_{2} \mathrm{O}_{3}$ のサンドブラスト処理の併用, ノンプレシャス系合金では $\mathrm{SiC}$ 研削材と $\mathrm{Al}_{2} \mathrm{O}_{3}$ のサンド ブラスト処理の併用と使い分ける場合が多い。こうした 理由は軟らかく伸びのよい合金を使用した場合では研削 時にできたバリの中に研削材の成分が入り込み，それら が残留したままの状態でポーセレンを焼成すると，ポー セレン焼成時に気泡が発生するからである。こうした気

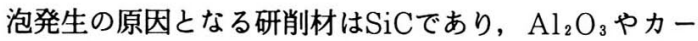
バイドバーでは問題はないのであるが，これらの研削材 は研削効率が低いため, 硬く研削に時間を要する合金で はSiCを使用した後, $50 \sim 70 \mu \mathrm{m}$ の $\mathrm{Al}_{2} \mathrm{O}_{3}$ のサンドブラ スト処理を行って $\mathrm{SiC}$ 残留物を除去する方法が採用さ れている。そして, $\mathrm{Al}_{2} \mathrm{O}_{3}$ のサンドブラスト処理はメ夕 ルキャップ表面に微細な凹凹が形成され，ポーセレンと の結合面積の増大にもつながるので, 結合強度の増大に 好都合である（図 5)。従って, プレシャス系合金, セ ミプレシャス系合金においても $\mathrm{Al}_{2} \mathrm{O}_{3}$ やカーバイドバー での研削の後, $\mathrm{Al}_{2} \mathrm{O}_{3}$ のサンドブラスト処理をする場合 が多い。以上は一般的に行われている機械的結合を求め る方法であるが，Ni-Cr-Mo系合金を使用した場合に結 合強度の不安から, 結合強度を向上させるために行われ ていた手法を次に紹介する。

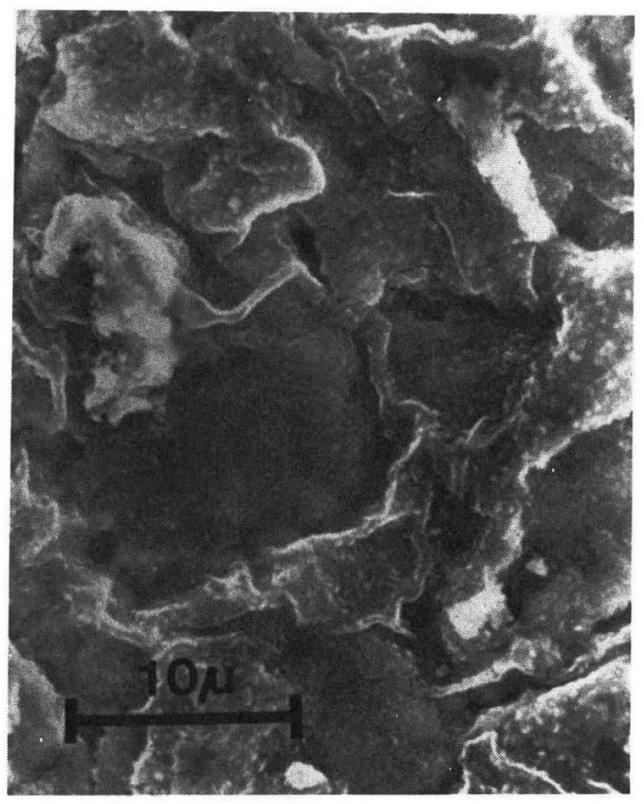

図 4 Beを含有しないNi-Cr-Mo系焼付用合金の酸化膜 加熱を絽り返すと酸化膜が成長し合金表面よりはく離 する。 $960^{\circ} \mathrm{C}$ で10分加熱後の写真（3000倍）

\section{6 機䂝的結合の特殊な方法}

2. 6. 1 プラズマ溶射法

歯科にプラズマ溶射法を心用したのは伊藤らであり ${ }^{11)}$, $\mathrm{Al}_{2} \mathrm{O}_{3}$ や安定化 $\mathrm{ZrO}_{2}, \mathrm{Ni}-\mathrm{Al}$ の粉末を溶射した場合, 表面あらさは30〜 $45 \mu$ となり, $\mathrm{Al}_{2} \mathrm{O}_{3}$ や $\mathrm{ZrO}_{2}$ は色調が 焼付用ポーセレンと類似していることもあり, メタルキャ ップと焼付ポーセレンの結合強度の向上と共に色調改善 にもつながるため, 注目を浴びた。しかし, 装置が大が かりすぎることや作業中に騒音と強い紫外線を伴うこと などから普及するにはいたらなかった。

2. 6.2 ガス火炎溶射法

この方法はプラズマ溶射法では前述した問題点があ ることから著者らが試みた方法であるが(2), $\mathrm{Al}_{2} \mathrm{O}_{3}$ ， $\mathrm{ZrO}_{2}$ を溶射した時では合金との密着性が低いため, 単 にNi-Cr-Mo系合金とポーセレンを焼付けた時より結合 強度が低下した。そして, サーメット材やNi-Alあるい はNi-Crの金属溶射材についても検討を行った。金属溶 射材の場合は比較的母合金との密着もよく, その結果メ タルキャップ表面に機械的維持を付与したことによりポー セレンとの結合強度の増大にはつながった。しかし，金 属溶射材の中で最も耐酸化性が少ないものといえどあポー セレン焼成中の加熱によって生成される緑色の酸化膜が ポーセレンの色調を阻害したり, ガス火炎溶射法はプラ ズマ溶射法に比べて気孔率が高いため, ポーセレン焼成 中にポーセレン中に気泡が生じやすかったなどの問題が 生じて,この方法も普及するにはいたらなかった。 

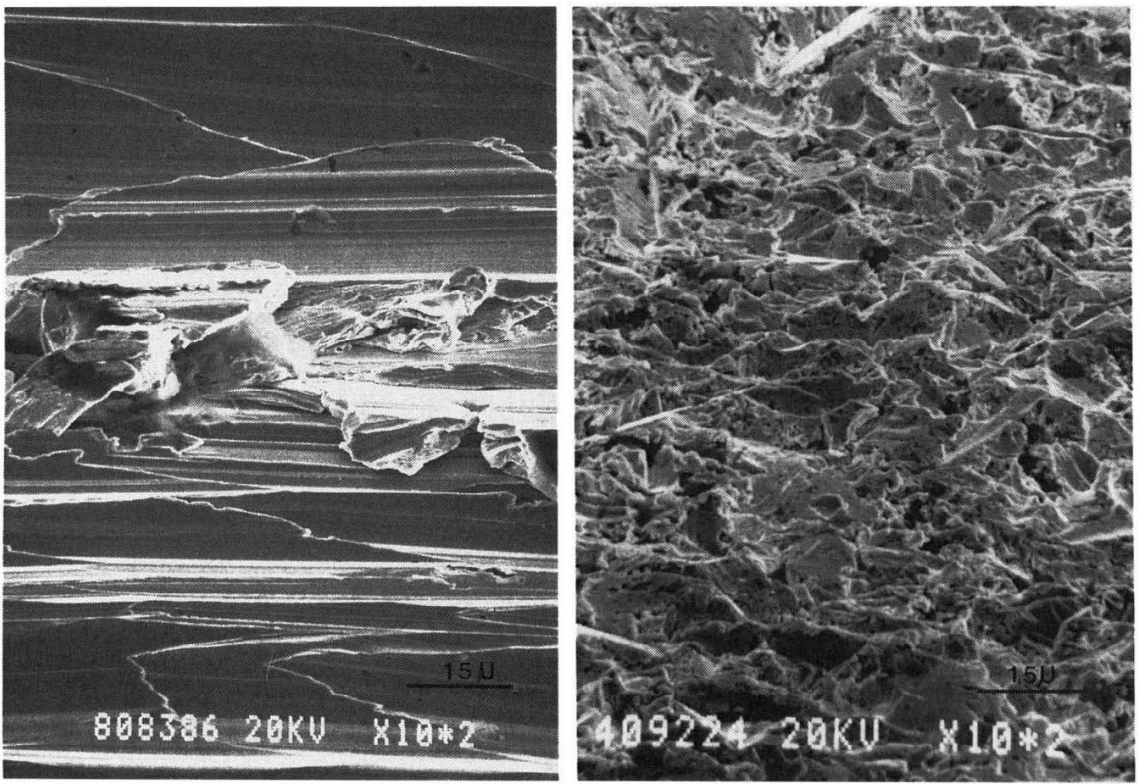

图 5 焼付用メタルキャップの表面仕上げ

左 : $\mathrm{SiC}$ 砥粒による研削のみ

右 : $\mathrm{Al}_{2} \mathrm{O}_{3}$ サンドブラスト処理後左右とも1000倍

\section{3. プラスチック材料と金属との結合における 表面処理}

\section{1 機械的維持}

プラスチックと歯科用合金の結合は一般的にはメタル キャップ表面に0.2mmほどの小粒の突起を付与し, 機 械的に維持を求めて行われている。その維持はワックス キャップ製作時にプラスチックのビーズを接着材を使用 して接着し，その状態で鋳型に埋入し，加熱して合金を 鋳造し，鋳造体となった時には機械的維持が多数付与さ れた状態となる。そして，外観にふれる部分にはプラス チック材料が焼付用ポーセレンの時と同様に不透明色か ら透明色まで層状に盛り上げ，加熱重合または光重合を 行って歯冠を形成する。プラスチック材としてはガラス とUDMA（ジウレタンジメタクリレート）をフィラー としUDMAやTEGDMA（トリェチレングリコールジ メタクリレート）をマトリックスとしたあのが多く使用 されている ${ }^{13)}$ 。また，合金としてはAu 12\%-Pd 25\%$\mathrm{Ag} 50 \%$ タイプの金銀パラジゥム合金, Au 62〜83\%Ag 5 〜 18\%-Cu 5 〜 16\%-Pt 0.2〜 $8 \%$ タイプの白金含 有合金やNi 32～92\%-Cr 6 20\%タイプのクラウンブ リッジ用Ni-Cr合金が使用されている。

\section{2 合金表面の酸化膜生成処理を応用した結合}

白金加熱合金や金銀パラジゥム合金を使用した場合に メタルキャップのプラスチック被着面を $400 \sim 500{ }^{\circ} \mathrm{C}$ で 3 分〜10分加熱して $\mathrm{Cu}_{2} \mathrm{O}$ の酸化膜を生成させ，その上に ポリマーとモノマーを混合して盛り上げて重合すると金
属とプラスチックの結合が増大する ${ }^{14)}$ 。また酸化剂溶液 浸せき法といって，酸化剤に浸せき後はCuOが生じる が，更に反応性に富んだ酸化膜 $\mathrm{Cu}_{2} \mathrm{O}$ にするため $120^{\circ} \mathrm{C}$ の電気炉で加熱する方法などがある ${ }^{15)}$ 。一方, Ni-Cr合 金ではCrは元来不動態の皮膜を6つが，それのみでは 結合強度が不足するので, 酸化剂浸せきや陽極酸化の処 理が必要である。酸化剂としては濃硝酸や過マンガン酸 カリウムの希硫酸溶液を使用して行われる。濃硝酸では 15〜30秒，過マンガン酸カリウムでは 5 ～20秒の浸せき 後エアーで乾燥して終了する。陽極酸化法は電解液に過 硫酸アンモニウムの水溶液を使用し，合金を陽極に固定 し通電して酸化処理を行う。以上のように酸化の手法は 合金別に分けられて行われるが, 酸化処理したメタルキャ ップの上に盛り上げられるプラスチック材はこの酸化膜 と反応性に富む必要がある。そのため, 第一層目に盛り 上げられるプラスチック材は 4-META/MMA-TBB系 が有名であり，これは 4-METAモノマーのトリメリッ 卜酸無水物基の酸素原子が水素結合を形成するのではな いかと報告されている。接着性モノマーとしてはこの他 にMDPモノマーがあり,これあリン酸基の酸素原子に よる水素結合であろうと報告されている ${ }^{16)}$ 。しかし，こ の結合が当初は強固であったとしても，プラスチック材 は口腔内の唾液などの水分によって性質が変化すること は避けることができないため, 安全策として先述した機 械的維持とを併用して行う場合がほとんどである。

\section{3 表面改質法の応用}

この方法は(1)スズ電析法, (2)シリコーター法がある。 
(1)のスズ電析法は合金表面を酸化させるのではなく，接 着性モノマーと接着しやすいスズおよびその酸化物で合 金表面を被覆する方法である ${ }^{17)}$ 。また(2)のシリコーター 法はテトラエトキシシランを火炎で分解しながら合金表 面に蒸着させると，合金表面はシリカやアルコキシシラ ンで覆われる。その上にシランカップリング剤を塗って, プラスチック材を接着する方法である ${ }^{18)}$ 。以上のように プラスチック材之金属との結合においてあ次から次へと 新しい技法が試みられ，これらは金属表面処理の改良; 開発にほかならない。

\section{4.おわりに}

人間の口の中はいつも唾液で満されており，食物の摄 取によって加熱, 冷却がたえず繰り返される環境下にあ る。そのため, 歯科用材料としては耐食性に優れ，毒性 のない材質はもちろんのこと，こうした環境下であ耐久 性に優れた材質であることが重要である。今回は歯冠修 復物の中で自然感と耐久性を兼ね備えた 2 つの代表的修 復物を挙げて，それぞれに応用されている金属の表面処 理を紹介した。現在，歯科においても他業種との交流， 技術交換が盛んに行われており，これらの交換を基礎と して将来ますます患者の役に立つ歯科材料，技術の発展 を望むあのである。

\section{文献}

1 ）星川 武; 大阪市立工業研究所報告, 1 105（1979）

2 ) 坂 清子, 服部智子, 藤木智之, 椭肇男, 笠井安紀子, 横地章生；歯科技工， 14，(4)，423（1986）

3 ) 坂 清子 ; 歯科技工, 15，(2)，182（1987）

4) 中山正彦; 陶材, p.47 (医歯薬出版, 1979)

5 ）三浦雅四，岡崎邦夫 ; 歯科ジャーナル，7，(5), 537 (1978)

6 ）宮川行男 ; 畨理工誌, 18, (44), 296 (1977)

7 ) 宮川行男 ; 歯理工誌, 19, (45), 15 (1978)

8 ) 坂 清子; Q\&Aセラモメタルサイエンス, p.11（医柬薬出 版, 1989)

9 ）坂 清子 ; 実践モラモメタルテクニック, p.16（医柬薬出 版, 1986)

10）野村順雄, 渡辺徹雄, 加藤治正, 長谷川二郎, 坂 清子 ; 第39回菌科理工学会抄録, p.44（1980）

11）伊藤充雄；雪理工誌，20，（51），167（1979）

12）坂 清子, 粕原肇男; 歯科技工, 11，(2)，135（1983）

13）中林宣男; 硬質レジンの世界, p.63（クインテッセンス出 版, 1989)

14）熱田 充, 松村英雄, 永野清司 ; 硬質レジンの世界, p.162 （クインテッセンス出版，1989）

15）田中卓男；接着ブリッジの臨床と雬科技工，p.61（医菌薬 出版, 1985)

16）増原英一 ; 接着ブリッジの臨床と歯科技工，p.59（医菌薬 出版, 1985)

17) 近藤康弘 ; 歯材器誌, 7, (1), 13 (1988)

18）森 栄, 河村訓陸, 岩井正彦, 加藤治正, 長谷川二郎 ; 愛院大歯誌, 25, 170 (1987)

(1989-9-18 受理) 